Review

\title{
Prospects and Challenges of Sugarcane Development in Nepal: Production, Market and Policy
}

\author{
${ }^{1}$ Amita Pandey and ${ }^{2}$ Sudip Devkota \\ ${ }^{1}$ Agriculture and Forestry University, Nepal \\ ${ }^{2}$ Ministry of Agriculture and Livestock Development, Government of Nepal, Nepal
}

\author{
Article history \\ Received: 28-03-2020 \\ Revised: 29-04-2020 \\ Accepted: 03-06-2020 \\ Corresponding Author: \\ Amita Pandey \\ Agriculture and Forestry \\ University, Nepal \\ Email: pandeyamita01.ap@gmail.com
}

\begin{abstract}
Sugarcane is a major cash crop and contributes 2.1\% in AGDP of Nepal. This paper attempts to review and analyze the status and issues of sugarcane subsector in reference with production, market and policies. Nepalese sugarcane production contributes less than $1 \%$ among SAARC countries and ranks 41 st position among global sugarcane production status. Per capita consumption of sugar in Nepal is $8 \mathrm{~kg} / \mathrm{year}$ and the annual production of the sugar contributes $60 \%$ of total national demand. Average recovery percentage of sugar in Nepal is very less $(8.83 \%)$ as compared to other major producer countries. Very limited research activities on varietal development and technology enhancement in sugarcane has been done by Nepal Agricultural Research Council. Policy intervention of government to promote sugarcane are mainly limited to cash subsidy to the farmers, simple technology extension services, fixation of minimum procurement price and farm facilitation. There is an absence of dedicated sugarcane development organization in present context. Delay payment to the farmers, traditional technologies, lack of high yielding varieties and poor access of farmers to the agriculture loan and insurance are found as major challenges of sugarcane production in Nepal. The study suggested to establish dedicated organization to promote the sugarcane technology extension and policy facilitation from the government. Establishment of quick and transparent payment mechanism to the farmers is must to encourage farmer for sugarcane cultivation in Nepal.
\end{abstract}

Keywords: Industry, Nepal, Sugar, Sugarcane

\section{Introduction}

Sugarcane is the largest commercial cash crop and contributes 2.1\% AGDP of Nepal (MoALD, 2019c). The commercial cultivation of sugarcane is common in plain area of the Tarai. It is only raw material for sugar production in Nepal. Others products made by crushing sugarcane are molasses, gud, gudgatta etc. Whereas the major byproducts of sugarcane are molasses, mud press, bagasse and ethanol (MoALD, 2020c). Sugarcane biomass in Nepal has high potential to produce bioelectricity with a range of 209-313 GWh that can provide power to operate and assist in local energy demand (Khatiwada et al., 2012). Sugarcane by-products like press mud and bagasse can be used as fertilizer which helps to improve physical, chemical and biological properties of soil, which ultimately increase crop yield and quality of agricultural produce. It also provides $\mathrm{N}, \mathrm{P}, \mathrm{K}, \mathrm{Fe}, \mathrm{Zn}, \mathrm{Mn}$ and $\mathrm{Cu}$ and reduces the extra cost of chemical fertilizers to the farmers (Dotaniya et al., 2016). Sugarcane is the main income source of more than 0.1 million of active sugarcane farmers (MoALD, 2020c). Sugarcane Research program established under Nepal Agricultural Research Council conducts sole research programmes in sugarcane (NARC, 2013). There are 14 sugar factories in operation, manufacturing the sugar. Further, the government organization like the Department of Agriculture (DoA), Crop Development and Agriculture Biodiversity Conservation Centre (CDABBC), Nepal Agriculture Research Council (NARC) are engaged in dissemination of new technologies (MoALD, 2020b; NARC, 2013). The domestic production of sugarcane in Nepal covers only $60 \%$ of sugar demand of the country (NSMA, 2018). Productivity and recovery rate of Nepalese sugarcane is lower in comparison to major trade partners like India and Pakistan. The cost of production of sugarcane and sugar is higher resulting the problems like delay payment and 
price exploitation (Neupane et al., 2017; Pokharel et al., 2019). In response to this, government is trying to address sugarcane problems with various policy efforts in price fixation, subsidization, extension, insurance and import substitution (MoALD, 2020b; 2020c). Critical analysis and a review of the existing policies, status of sugarcane industries and market dynamics in sugarcane is required to explore opportunities and challenges of Nepalese sugarcane industry. Policy recommendation and suggestion from this study may help policy makers and other stakeholder to develop sustainable sugarcane development programs.

\section{Materials and Methods}

The study is based on review of secondary data. The source of secondary data was official reports, documents and publications of government organizations like the Ministry of Agriculture and Livestock Development (MoALD), Ministry of Finance (MoF), National Planning Commission (NPC), National Industrial Crop Development Program (NICDP), Nepal Agriculture Research Council (NARC), National Sugarcane Research Program (NSRP) and Nepal Sugar Mill Association (NSMA). Similarly, the academic research articles were also reviewed. The prospects and challenges, including strength, weakness, opportunities and threats of sugarcane industry are explained in discussion and simple excel techniques were used to generate graphs and chart.

\section{Results and Discussion}

\section{Global Position of Nepal in Sugarcane Production}

Nepal ranks 41th position in sugarcane production in global production scenario (Neupane et al., 2017). Further, Nepal ranked 4th position and shared $0.83 \%$ of production among the SAARC countries, where India is the largest producer of sugarcane followed by Pakistan and Bangladesh (Table 1). Among SAARC countries, India and Pakistan are exporting sugar in global market. Nepal imports substantial amount of sugar and sugar products from India and Pakistan mainly (FAOSTAT, 2018).

\section{Sugarcane Production in Nepal}

Sugarcane is largest commercial cash crop of Nepal (MoAD, 2013a; 2014; 2015; 2016; MoALD, 2017; 2019a; MoALMC, 2018b). Since the ancient time, sugarcane cultivation is in practice, but commercial cultivation is assumed after the establishment of Morang sugar mill limited in 1947 (Rathi, 2018). Sugarcane cultivation is in 41 districts of Nepal but commercial cultivation is only in 14 districts (MoALD, 2020c). There are around 0.1 million commercial sugarcane farmers in Nepal (MoALD, 2020c). Higher production of sugarcane is in province 2 than other provinces. The favorable tropical climatic features (MoALMC, 2018a), concentration of sugarcane factories and presence of National Sugarcane Research program are major reasons behind the large area expansion of sugarcane in province 2 (MoALMC, 2018a; 2018b).

Sugarcane is extended in 78,609 hectares (ha) of area with average productivity of $45.26 \mathrm{MT} / \mathrm{ha}$ (MoALD, 2019a). In 2018/19, production was estimated to be increased by $12.7 \%$, but production was increased by $2.8 \%$ only (MoALD, 2019a; MoF, 2018a). The productivity and area of sugarcane has decreased since 2015 (Fig. 1). The productivity of sugarcane is restricted to $45 \mathrm{MT} /$ ha only which is comparatively very low when compared with the actual productivity of the varieties released or introduced (MoALD, 2020c; Neupane et al., 2017; Pokharel et al., 2019; MoALD, 2018).

\section{Research and Variety Development Activities of Sugarcane in Nepal}

National Sugarcane Research Program (NSRP), Bara established under Nepal Agriculture Research Council (NARC) is only a responsible research organization to generate sustainable, environment friendly and economically viable technologies and carry the breeding and development program for sugarcane in Nepal (NARC, 2013). Most of the researches are on nutrient management practices, intercropping, weed management, pest management, mechanization and other socioeconomic aspect of the sugarcane industry (NARC, 2017; NSMA, 2018). Whereas, research program in sugarcane breeding and varietal development is comparatively lower. There are only four released varieties and only twelve improved varieties in the process of registration. These varieties are recommended in some domain of Nepal. NSRP has classified different varieties as early, mid and late on the basis of performance trial (MoALD, 2020c; NARC, 2017).

Similarly Agricultural Engineering Division under NARC, Agricultural Engineering Directorate under Department of Agriculture and Purbanchal Campus, Institute of Engineering under mechanization in Nepal respectively, are the institutes related with research, development and promotion of the machines and equipment in Nepal (Manandhar, 2005; Shrestha, 2012).

Sugarcane is a perennial crop which requires a long period of time and large amount of budget for qualitative research. The budget allocation for the research and development of the sugarcane is very low, further the trend shows decrease in budget after 2017/18. The limited budget allocation in this subsector limits the research programs through shrinkage of research activities, resources, locations and areas for trial. In this situation research program is unable to extend in sugar-mills and concentrate its research programs in province number 2 only (MoALD, 2020c; MoF, 2018a; 2019; Sapkota et al., 2017). 


\section{Agriculture Inputs for Sugarcane Production}

There is annual provision of subsidized chemical fertilizer to the farmer. To make the sufficient and cheap availability of fertilizers, around 348 thousand MT chemical fertilizers was disbursed in 2019/20(MoALD, 2019a). Similarly, the use of mechanical power is in increasing order (MoAD, 2017). There are some power-operated agricultural machines like: Water pumps; tractors; harrows; rotavators and laser land-levelers particularly in Tarai regions of Nepal (Justice and Biggs, 2013). Similarly, 1.4 million ha of land has irrigation facilities in Nepal (NPC, 2020). The underground water irrigation for shallow and deep tubules in tarai region has increased to 0.4 million ha (MoEN, 2018) which has increased the scope for sugarcane production.

Despite of these government efforts, still there is insufficient chemical fertilizers (MoF, 2018a), rainfed sugarcane farming (IBN, 2018), poor access to modern machineries and few high yielding varieties (Neupane et al., 2017; Pokharel et al., 2019; Takeshima, 2017) as major limiting factors to attain higher yield of sugarcane. Adequate and timely supply of quality inputs such as seeds, plant protection chemicals, bio-pesticides, agricultural machineries and agricultural credit at reasonable rates to farmers constitute the key problems in sugarcane cultivation (MoAD, 2013b; MoALD, 2020c; Neupane et al., 2017; NSMA, 2018; Pokharel et al., 2019).

\section{Industrial Development in Sugarcane Subsector of Nepal}

Sugar industry substituted complete dependency over the sugar with India. Figure 2 depicts increased sugarcane production with increasing number of sugarmills (MoALD, 2020b; 2020c; Rathi, 2018). From 1946 to 2018, 34 sugar-mills including medium and large scale sugar-mills were registered in Nepal. Since 2017, there is no registration of new sugar-mills in Nepal. Among 34 registered sugar-mill, 20 sugar-mills are not in operation. Only 14 sugars-mills including many small scale sugar refining industries (Khandsari) producing Sakhar (Gud and Bheli) are in operation. The crushing capacity of the Nepalese sugar industry ranges from 500 to 50000 Quintal/day, with annual capacity to produce 903,155 MT of sugar. But the sugar-mills are running below the full crushing capacity, manufacturing only 830,255 MT of sugar (MoALD, 2020c).

Table 1: Comparative analysis of sugarcane production among SAARC countries

\begin{tabular}{llrrr}
\hline S.No. & Country & Area $(000 \mathrm{ha})$ & Production $(00000 \mathrm{MT})$ & Yield $(\mathrm{MT} / \mathrm{ha})$ \\
\hline 1 & India & 4389.00 & 30600.0 & 69.72 \\
2 & Pakistan & 1216.90 & 7340.0 & 60.32 \\
3 & Bangladesh & 92.00 & 386.3 & 41.96 \\
4 & Nepal & 71.47 & 323.5 & 45.26 \\
5 & Srilanka & 17.90 & 65.5 & 36.56 \\
6 & Afghanistan & 1.15 & 3.4 & 29.45 \\
7 & Bhutan & 0.48 & 1.5 & 31.28 \\
\hline
\end{tabular}

Source: (FAOSTAT, 2018)

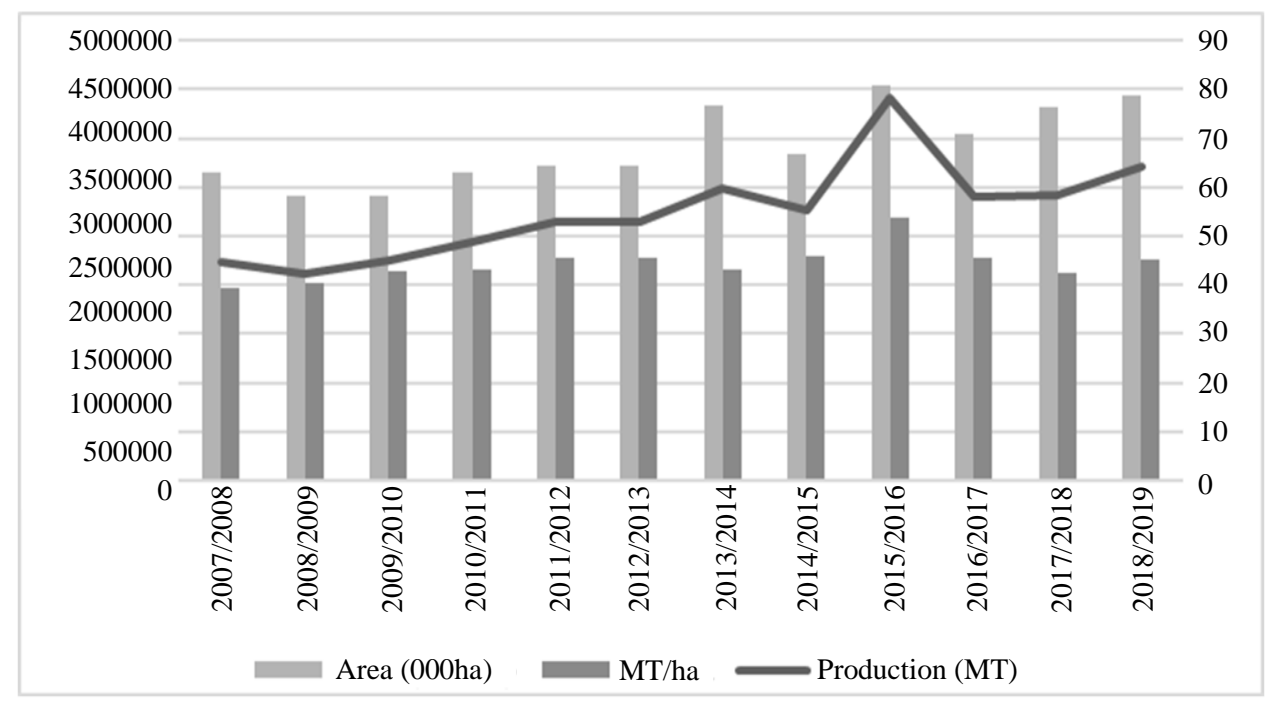

Fig. 1: Area, production and productivity of sugarcane in Nepal Source: (MoALD, 2017; 2019a) 


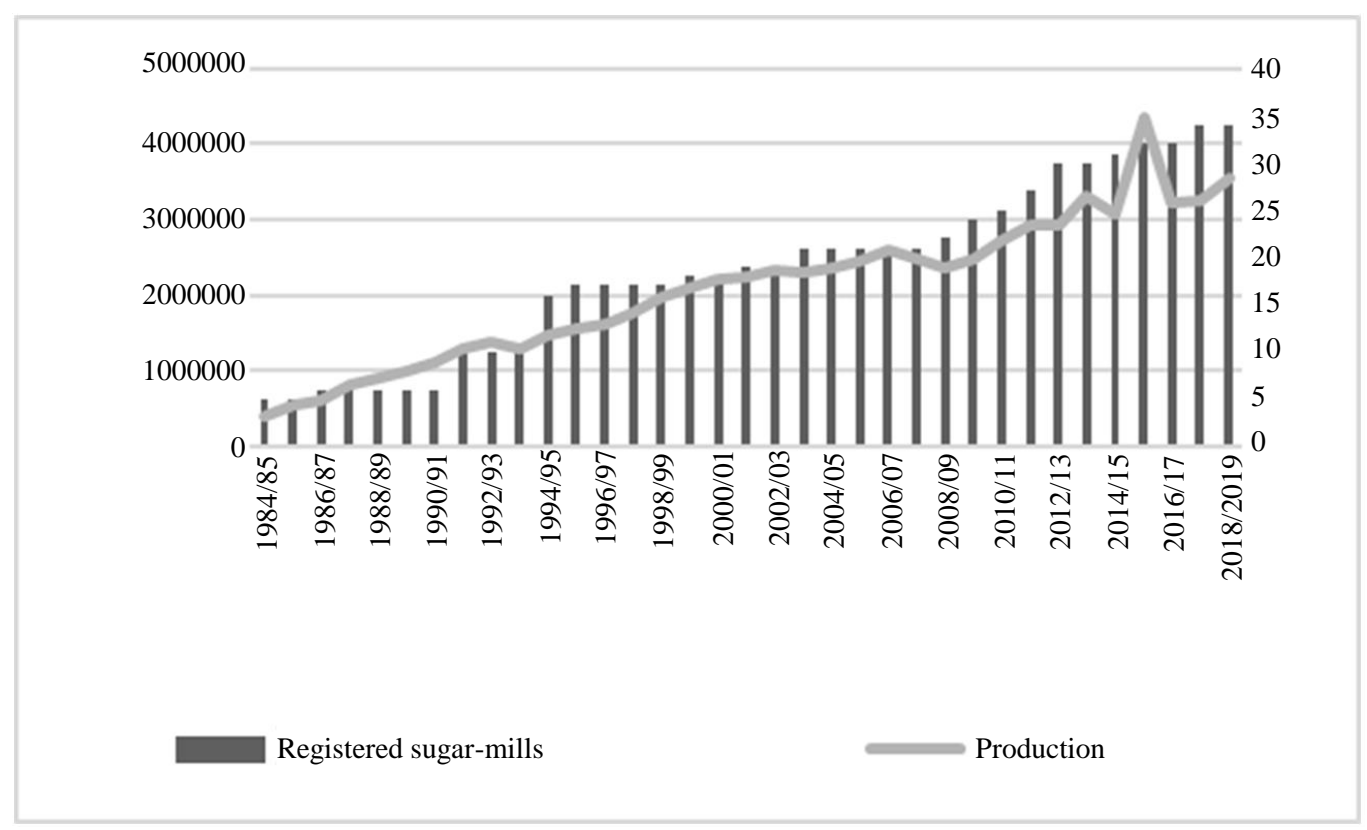

Fig. 2: Trend of sugarcane production in relation to number of sugar-mills registered Source: (MoAD, 2013a; MoALD, 2017; 2019a; 2020b; Rathi, 2018)

The domestic production and supply of sugarcane is lower than crushing capacity of mills. The seasonal and lower supply of canes has led sugar-mills to operate for a short crushing period around 4 to 7 months a year (Sapkota et al., 2017). Similarly, the recovery percentage of Nepalese sugarcane is very low (8.83\%) (MoALD, 2020c). Further, physical capacity utilization of existing sugar-mills are in decreasing trend $61 \%$ in $2000-01,40 \%$ in $2009 / 10$ and $38.79 \%$ in 2019 due to continuous use of old, traditional and inefficient machines (Rathi, 2018; Sapkota et al., 2017). All these factors are responsible for lower production of sugar in Nepal. Moreover, the cost of manufacture is high with lower margin due to insufficient and poor quality supply of sugarcane, financial problem due to seasonal operation of sugarmills, inefficient old machines, higher processing loss, expensive manufacturing ingredients and uniform price for different quality sugarcane (Alam et al., 2009; NSMA, 2018).

The existing market price of subsidized sugar ranges from NRs 65 to 70/kg, similarly the price in the Indian border market is around NRs $45 / \mathrm{kg}$. But the domestic price of sugar manufactured in Nepalese sugar-mill is NRs $87.61 / \mathrm{kg}$, higher than the former sugar (NSMA, 2018; Sapkota et al., 2017). The exporting countries like India and Pakistan provide the export subsidy, which made their sugar cheaper than Nepalese sugar. Huge amount of subsidized sugar of other countries are exported in Nepal and heavy amount of sugar produced by the domestic sugar mill is dumped in go down yearly. The total amount of 165,132 MT of subsidized sugar was dumped in 2017-18 as surplus stock (NSMA, 2018). The surplus stock in Nepal is increasing in trend (Fig. 3).

\section{Trade of Sugar in Nepal}

In 2017/18 the annual production of the sugar in Nepal was 179,250 MT with annual consumption of 250,000 MT. The domestic production of sugar meets only the $60 \%$ of consumption demand, whereas the remaining $40 \%$ is fulfilled by importing sugar (NSMA, 2018). In general, sugar extracted from sugarcane and sugar beet is imported to Nepal. Sum total of 235,882 MT of refined sugar was imported in 2017/18 out of which 2929 MT was khanda sugar (HS code of 17011320) and 3092.5 MT was sakhar (Gud\&veli) and Gudgatta (HS code of 17011410 and remaining quantity were other products of sugarcane and sugar-beets $(\mathrm{MoF}$, 2018b) (Fig. 4). The main countries exporting the sugar to Nepal were India, Pakistan, Brazil and China (MoF, 2018b). The import of the sugar was increased tremendously in 2016 and 2017 (MoF, 2018b). The major trade partner India has heavily subsidized the sugar to promote the export and increased the import duty to $100 \%$ to reduce the domestic surplus stock of sugar (MoCAFPD, 2019). But, import duty of sugar in Nepal is extended from $15 \%$ to $30 \%$ only (MoF, 2018a). Thus import can be substituted with further increasing import duty in sugar. 


\section{Organizations Involved for Sugarcane Development in Nepal}

The organized sugarcane development program was started after establishment of National Industrial Crop Development Program (NICDEP) in 2004, under Department of Agriculture (NICDEP, 2018). In 2010, National Sugarcane and Sugar Development Committee (NSSDC) was formed to handle the issues of sugarcane development. Both organizations played a crucial role for extension of sugarcane technologies to the rural farmers. Major activities conducted were training, distribution of small machineries, organization of workshop, market facilitation and policy facilitation in local as well as central level. Different I/NGOs, CBOs, cooperatives and farmers groups has valuable contribution on sugarcane development in Nepal (MoALD, 2020b).

However, with the restructuring of the government organization in 2075, sugarcane subsector related organizations were dismissed and responsibility of sugarcane promotion has transferred to provincial and local government also (MoALD, 2020b).

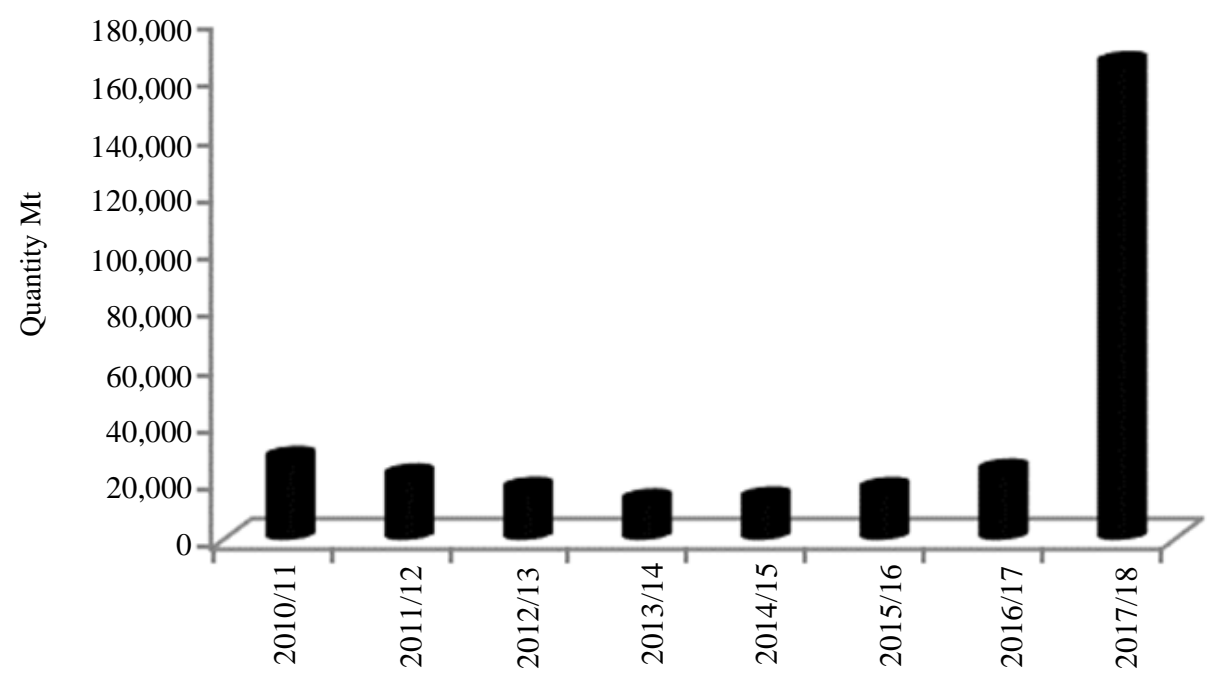

Fig. 3: Surplus Sugar stock in Nepal at different time period. Source: (NSMA, 2018)

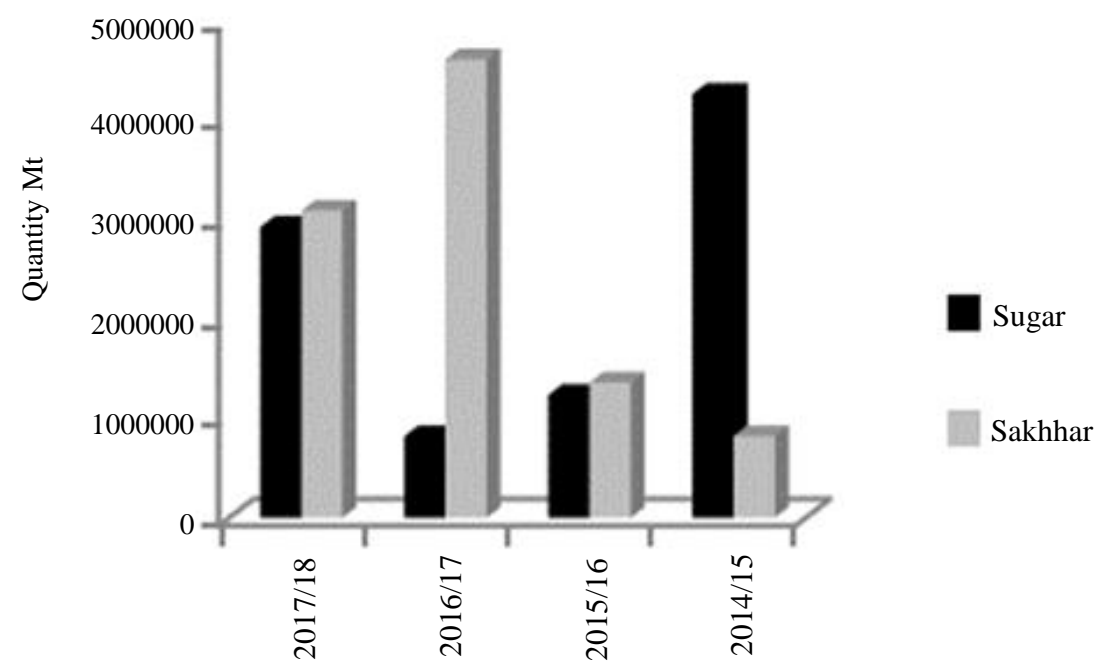

Fig. 4: Import of Sugar and Sakhhar in Nepal (2014/15-2017/18) Source: (MoF, 2015; 2016; 2017; 2018b) 


\section{Government Initiatives to Promote Sugarcane in Nepal}

In 2013, to promote the sugar refining industry, Government of Nepal made Sugarcane Promotion Implementation working modality 2070 (MoAD, 2013b). The modality focused on extension of production and promotion of refining activities for the sugar industry, raw materials supply to established sugar factory, development of the local level sugarcane refining programs, providing the training, visit and demonstration to the sugarcane farmers for capacity buildings. Further the model included a monetary subsidy for establishment of khandsari and installment of sugar refining machineries and equipment's. Similarly to promote mechanization and adoption of advance technologies, demonstration programs like use of modern machines, advance cultivation practices, inter-cropping practices and participatory varietal selection were included. Further for skills development, publications and trainings were prioritized. But the modality was dismissed with the restructuring of organizational structure (MoAD, 2013b). After 2019, five years sugarcane promotion program (MoALD, 2020a) was implemented to promote sugarcane. Further, the market information system was planned to provide information on the price of the agricultural yield and minimize the risk of investment in agriculture sector to be caused by weather and climate change a through mobile process (MoF, 2018a). Similarly, crop insurance for farmer security is introduced, where $75 \%$ of the insurance premium for agriculture including sugarcane insurance is subsidized by GoN (MoALD, 2019a; MoF, 2018a). As sugarcane promotion subsidy, productionbased grants is provided to the farmers (MoALD, 2019b).

The planned and implemented programs are not running at the expected speed with expected results. Thus a separate dedicated organizational structure is required for extension and policy formulation.

\section{Cost of Sugarcane Production}

Government of Nepal provides subsidies on chemical and organic fertilizers, machineries, insurance services and even declared procurement price for sugarcane (IBN, 2018; MoALD, 2020c). Despite of these facilities, the cost of sugarcane cultivation is still higher in Nepal NRs 469/quintal (Neupane et al., 2017; Sapkota et al., 2017). More than half of the cost of production is accounted by labor. Further, the cost of setts, chemical fertilizers, manure and land preparation is higher. Thus small-scale and labor-intensive farming, low productivity and higher cost of inputs of sugarcane are major reasons for the high cost (Pokharel et al., 2019; Sapkota et al., 2017). B:C ratio of the sugarcane is only 1.17 (Neupane et al., 2017) which is insufficient for livelihood improvement of the producers. Though intercropping in sugarcane give a higher BC ratio 4 to 5 (Rehman et al., 2014), it is not commonly practiced in Nepal. Thus, there is less profit margin in sugarcane (NSMA, 2018).

\section{Price and Market of Sugarcane}

The price of sugarcane is estimated with common understanding between line ministries and other sugarcane stakeholders. Every year before harvesting of sugarcane, Minimum Procurement Price (MPP) is declared incorporating cost of production, a certain percentage of benefit and production based subsidy (Fig. 5) (MoALD, 2019b; 2020c). The MPP of 2019/20 was NRs 536.56/quintal including production based subsidy NRs 65.28/quintal (MoALD, 2019b). However, sometime there is a delay in declaration of MPP that coincides with harvesting period. In this situation there is a risk of postharvest loss of sugarcane, so farmers sell the harvested sugarcane in lower price (Chhetri, 2018).

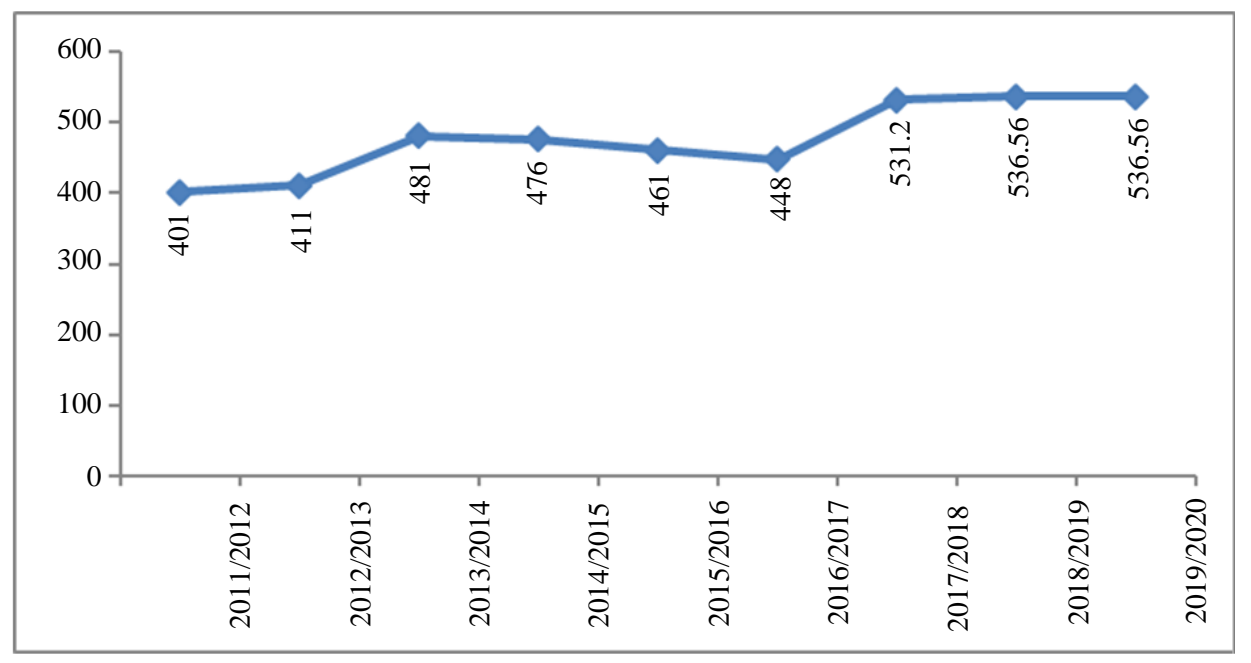

Fig. 5: Trend of MPP (NRs/quintal) for sugarcane in Nepal Source: (MoALD, 2020b) 
The price policy and lower cost of production in India has direct effect in Nepalese sugar market. The India's Fair Remunerative Price (FRP) system of sugarcane considers farmers, manufacturers and consumers. More than MPP, FRP includes the factors like return to the growers from alternative crops, margin for growers on account of risk and profit, recovery rate, the imputed value of byproducts, the price of sugar sold by sugar producers and fair price of sugar available to consumers. Similarly, FRP is also address byproducts of sugarcane (ethanol, bagasse and molasses) to promote the quality and market extension of sugarcane byproducts. Fair Remunerative price not only protect the interest of farmers but encourage and rewards with premium price for the higher sugar recovery rate. Further the declaration of Minimum Selling Price (MSP) of sugar has protected sugar-mills to cover the cost of production of sugar and pay the dues of farmers (MoCAFPD, 2019).

However, the Nepalese sugarcane price never gets a logical price based on the actual production cost and quality of sugarcane (Neupane et al., 2017). Thus sugar mill are reluctant to pay the uniform Price (MPP) for the various cane qualities and disputes arises between the farmers and sugar-mills (NSMA, 2018). After disputes, major problems like sudden closing and delay opening of sugar- mills, delay and incomplete payment to the farmers and price fluctuations initiates in market (Neupane et al., 2017; Pokharel et al., 2019; Sapkota et al., 2017). Furthermore, these disputes directly hamper in postharvest life i.e., recovery rate and weight of cane and ultimately farmers are compelled to sell their cane below the MPP in small scale sugar refining industries (Khandsari) which are not included in price policy of government (MoALD, 2019b).

\section{Conclusion}

As largest cash crop, sugarcane plays an important role for the livelihood of Nepalese farmers as a direct source of income. There are global as well as local challenges in sugarcane farming and marketing. The national production of sugar cannot meet the internal demand due to lower production and capacity utilization of sugar-refining industries. The labor intensive sugarcane farming is responsible for the high cost of production and low profit margin for both farmers and sugar-mills. Investment in programs related to research, varietal development and extension of advance technologies is most necessary. Further, the guarantee supply of sufficient and subsidized agricultural commodities like high yielding varieties sets, modern agri-machineries, organic and inorganic fertilizers, irrigation infrastructures and plant protection measure are boon for higher production and revenue. The restructured local, province and central government should establish dedicated sugarcane subsector organizations for effective, smooth and fast implementation and operation of the sugarcane related programs and policies.

The existing sugar-mills has a significant role for increasing the production, but capacity utilization and cost efficiency of factory is low. To protect both the sugar-mills and farmers, some adjustment is essential in existing trade and price policy. Increase in import duty, estimation of logic price of sugarcane including recovery rate helps to reduce the market distortion. Further the price policy should be extended to sugar and sugarcane byproducts which ultimately enhance the financial status of sugar-mills and enable for dues payment of farmers. The quick and transparent payment mechanism in close coordination with line ministries, farmers associations and sugar industries help to protect the sugarcane farmers of Nepal. Protecting all the actors of sugarcane industries through effective price and trade policy helps to reduce the financial burden and enhance the domestic production and consumption. Thus the sound economic balance can exist in the sugarcane industry.

\section{Acknowledgement}

We would like to express our deepest gratitude to sugarcane farmers, Ministry of Agriculture and Livestock Development and other organizations for providing the information for this article.

\section{Authors Contributions}

All authors equally contributed in this work.

\section{Ethics}

This article contains secondary information and it is a review paper. The corresponding author confirms that the other author read and approved the manuscript and no ethical issues involved.

\section{References}

Alam, M., G. Alam, M. Miah and S. Rahman, 2009. Factors affecting sugar recovery of Bangladesh sugar industry. Pak. Sugar J.

Chhetri, T., 2018. Farmers compelled to sell sugarcane at lower prices. My Republica.

Dotaniya, M.L., S.C. Datta, D.R. Biswas, C.K. Dotaniya and B.L. Meena et al., 2016. Use of sugarcane industrial by-products for improving sugarcane productivity and soil health. Int. J. Recycl. Organic Waste Agric., 5: 185-194. DOI: $10.1007 / \mathrm{s} 40093-016-0132-8$

FAOSTAT, 2018. http://www.fao.org/faostat/en/\#data/QC
Crops. 
IBN, 2018. Agriculture sector profile. ICC Complex, New Baneshwor, Kathmandu, Investment Board Nepal, Ministry of Industry, Government of Nepal, Nepal.

Justice, S. and S. Biggs, 2013. Rural and agricultural mechanization in Bangladesh and Nepal: Status, processes and outcomes. Mechanization for Rural Development: A Review of Patterns and Progress from Around the World. Food Agric. Organizat. United Nations.

Khatiwada, D., J. Seabra, S. Silveira and A. Walter, 2012. Power generation from sugarcane biomass-A complementary option to hydroelectricity in Nepal and Brazil. Energy, 48: 241-254.

DOI: 10.1016/j.energy.2012.03.015

Manandhar, G., 2005. Agricultural engineering research and development in Nepal. Proceedings of the 1st United Nations Asian and Pacific Centre for Agricultural Engineering and Machinery, (AEM' 05), Meeting, New Delhi, India.

MoAD, 2013a. Statistical information on Nepalese agriculture 2012/2013. Government of Nepal, Ministry of Agricultural Development, Agribusiness Promotion and Statistics Division, Agri Statistics Section, Singha Durbar, Kathmandu, Nepal.

MoAD, 2013b. Sugarcane cultivation extension and promotion working modality, 2070. Ministry of Agricultural Development, Government of Nepal, Hriharbhawan, Lalitpur, Nepal.

MoAD, 2014. Statistical information on Nepalese agriculture 2013/2014. Government of Nepal, Ministry of Agricultural Development, AgriBusiness Promotion and Statistics Division, Agri statistics section, Singha durbar, Kathmandu, Nepal.

MoAD, 2015. Statistical information on Nepalese agriculture 2014/2015. Agri Statistics Section, Agribusiness Promotion and Statistics Division, Ministry of Agricultural Development, Singha Durbar, Kathmandu, Nepal.

MoAD, 2016. Statistical information on Nepalese agriculture 2015/16. Government of Nepal, Ministry of Agricultural Development, Monitoring, Evaluation and Statistics Division, Agri Statistics Section, Agri Statistics Section, Singha durbar, Kathmandu, Nepal.

MoAD, 2017. Nepalese agricultural mechanization policy and strategy. Proceeding of the 5th Regional Forum on Sustainable Agricultural Mechanization in Asia and the Pacific, (MAP' 17), Ministry of Agricutural Development, Kathmandu, Nepal.

MoALD, 2017. Statistical information on Nepalese agriculture 2016/17. Agriculture Statistics Section, Monitoring, Evaluation and Statistics Division, Ministry of Agriculture, Land Management and Coperatives, Singh durbar, Kathmandu, Nepal.
MoALD, 2018. Krishi diary. Governement of Nepal, Agriculture, Land Mangemnet and Cooperatives Ministry, Agriculture Information and Communication Center, Hariharbhawan, Kathmandu.

MoALD, 2019a. Agriculture diary. Hariharbhawan, Kathmandu: Governement of Nepal, Ministry of Agriculture and Livestock development, Agriculture Information and Technical training.

MoALD, 2019b. Price fixation of sugarcane by government.

MoALD, 2019c. Selected indicators of Nepalese agriculture and population. Ministry of Agriculture and Livestock Development, Kathmandu, Nepal.

MoALD, 2020a. Annual report 2019/20. Ministry of Agriculture and Livestock Development, Government of Nepal, Singhadurbar, Kathmandu, Nepal.

MoALD, 2020b. Sugarcane cultivation in Nepal. Ministry of Agriculture and Livestock Development. Singhadurbar, Kathmandu.

MoALD, 2020c. Sugarcane development in Nepal (in Nepali). Ministry of Agriculture and Liveatock Development, Singhadurbar, Kathmandu, Nepal.

MoALMC, 2018a. Final report, inter provincial dependency for agricultural development. Hariharbhawan, Lalitpur, Nepal.

MoALMC, 2018b. Statistical information on Nepalese agriculture 2017/18. Agriculture Statistics Section, Monitoring, Evaluation and Statistics Division, Ministry of Agriculture, Land Management and Coperatives, Kathmandu, Nepal.

MoCAFPD, 2019. Sugarcane pricing policy. Department of Food and Public Distribution, Ministry of Consumer Affairs, Food and Public Distribution, Government of India, India.

MoEN, 2018. Energy, water resources and irrigation present conditon and future pathways. Ministry of Energy, Water Resources and Irrigation, Kathmandu, Nepal.

MoF, 2015. Nepal foreign trade statistics fiscal year 2014/15 (2071/72) part I. Government of Nepal Ministry of Finance, Tripureshwor, Kathmandu.

MoF, 2016. Nepal foreign trade statistics fiscal year 2015/16 (2072/73). Government of Nepal, Ministry of Finance, Tripureshwor, Kathmandu.

MoF, 2017. Nepal foreign trade statistics fiscal year 2016/17. Government of Nepal, Ministry of Finance, Tripureshwor, Kathmandu.

MoF, 2018a. Budget speech of fiscal year 2018/19. Government of Nepal, Ministry of Finance, Kathmandu, Nepal.

MoF, 2018b. Nepal foreign trade statistics: Fiscal Year 2017/18 (2074/75). Ministry of Finance, Goverrnment of Nepal, Tripureswor, Kathmandu, Nepal. 
MoF, 2019. Budget speech of fiscal year 2019/20. Government of Nepal, Ministry of Finance, Kathmandu, Nepal.

NARC, 2013. National sugarcane research program.

NARC, 2017. Annual report 2016-17. Khumaltar, Lalitpur, Nepal.

Neupane, P.R., T.N. Maraseni and M. Köhl, 2017. The sugarcane industry in Nepal: Opportunities and challenges. Environ. Dev., 24: 86-98.

DOI: 10.1016/j.envdev.2017.02.001

NICDEP, 2018. http://nicdep.gov.np/about-us

NPC, 2020. Periodic fifteen plan approach paper (2076/77-2080/81). Nepal Planning Commission, Singhhadurbar, Kathmandu, Nepal.

NSMA, 2018. Sugar industry crisis; Presented by Nepal sugar mill association. Nepal Sugar Mills Association, Kathmandu, Nepal.

Pokharel, D., R. Uprety, S. Mehata, H.K. Shrestha and D. Panday, 2019. Dynamics and economic analysis of sugarcane production in eastern plains of Nepal. Current Agric. Res. J., 7: 201-212.

DOI: 10.12944/carj.7.2.08
Rathi, R.S., 2018. Performance appraisal of sugar industry of Nepal.

Rehman, A., R. Qamar and J. Qamar, 2014. Economic assessment of sugarcane (Saccharum officinarum L.) through intercropping. J. Agric. Chem. Environ., 3: 24-24. DOI: 10.4236/jacen.2014.33B004

Sapkota, S., S. Gairhe, N. Upadhyay and Y. Acharya, 2017. Problems and opportunities in sugarcane production and marketing in Nepal. Proceedings of the 30th National Winter Crops Workshop, (WCW' 17).

Shrestha, S., 2012. Status of agricultural mechanization in Nepal. United Nations Asian and Pacific Center for Agricultural Engineering and Machinery.

Takeshima, H., 2017. Overview of the evolution of agricultural mechanization in Nepal: A focus on tractors and combine harvesters. Int. Food Policy Res. Inst. 